\title{
曲げ圧縮破壊する耐震壁の曲げ変形性能に対する拘束域の影響因子 STRUCTURAL PARAMETERS OF CONFINED AREA AFFECT FLEXURAL DEFORMATION CAPACITY OF SHEAR WALLS THAT FAIL IN BENDING WITH CONCRETE CRUSHING
}

\author{
松原聡平*, 真田靖士**, 谷 昌典 ${ }^{* * *}$, 高橋 之**** \\ 市之瀬 敏勝*****, 福山 洋****** \\ Sohei MATSUBARA, Yasushi SANADA, Masanori TANI, \\ Susumu TAKAHASHI, Toshikatsu ICHINOSE and Hiroshi FUKUYAMA
}

\begin{abstract}
This paper summarizes experimental results of 13 shear wall specimens with different structural details of confined area at wall end. Experimental results revealed that flexural deformation capacity of the specimens increased with existence of boundary column, expansion of confined area, application of hoops, etc. Moreover, structural parameters of confined area related to flexural deformation capacity were investigated to propose some key parameters for designing shear walls that fail in bending with concrete crushing. Axial/shear stress of confined area was found to be closely related to flexural deformation capacity of shear walls.
\end{abstract}

Keywords : Reinforced concrete, Structural wall, Seismic design, Laboratory test, Axial stress, Shear stress 鉄筋コンクリート, 而震壁, 而震設計, 構造実験, 軸応力度, せん断応力度

1.はじめに

2010 年の RC 規準の改訂により, 耐震壁の設計自由度が大幅に拡 大され，壁板端部に柱型がない耐震壁の許容応力度設計が可能とな

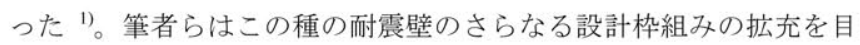
的に実験的，解析的な検討を進めている。中でも保有水平耐力設計 を行う枠組みの構築は喫緊の課題であり, その実現には強度および 変形性能の評価法が不可欠である。とくに後者については, いわゆ る部材種別 ${ }^{2)}$ の設定を前提に, 変形性能に影響を与える各種構造因 子を特定し，両者の関係を定量的に評価する必要がある。

壁板端部に柱型がない耐震壁は断面圧縮域の軸力負担が大きくな り，曲げ圧縮破壊により限界変形性能に達寸る傾向がある。2010 年 改訂以前の RC 規準 ${ }^{3)}$ では耐震壁に側柱の設置に関する規定が存在 した。そのため, 曲げ圧縮破壊する耐震壁の性能を陽に評価した研 究は, コア壁のような拘束域に密な配筋がある高層の壁を除くと, 数が限られる。例えば平石らは, 壁板に直交する偏平な壁柱は有す るが，圧縮域の拘束筋が比較的疎な曲げ破壞型耐震壁を含む一連の 実験を報告しており, その変形性能には柱の圧縮応力度が影響する ことを指摘している ${ }^{4)}$ 。近年では, 阪本らが枠柱の有無と拘束域の 補強量を変動因子とした実験を行い, 変形性能への影響を検証して
(る ${ }^{5)}$ 。これら既往の研究では曲げ圧縮破壊する而震壁の変形性能 と構造因子の関係, とりわけ大きな影響が予想される拘束域の構造 因子との関係までは分析されていない。

海外では 2010 年チリ・マウレ地震により高層住宅の耐震壁の曲げ 圧縮破壊に起因する被害が発生した ${ }^{6}$ 。圧縮域の軸力負担が大きく, 拘束筋も比較的疎である耐震壁の曲げ破壊が改めて注目され, 構造 性能の分析が進められている7)。

一方, 筆者らの既往の研究に焦点を移すと, とくに文献 8)では, 壁板端部で曲げ圧縮破壊する耐震壁の試験体 10 体の実験を行い, そ の変形性能を実験的に評価するとともに, マクロ挙動をモデル化し, 曲げ変形性能を評価する方法を示した。こうした破壊性状を示寸耐 震壁では, 端部拘束域の構造詳細により変形性能が影響を受けると 予想されたが，既往の研究ではその影響を抽出するまでの実験デー

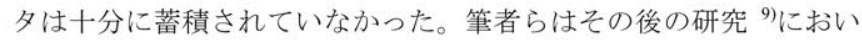
て, 壁板端部の構造詳細をパラメータとする実験を継続的に赛施し, 実験データの蓄積が進んでいる。

以上のような背景の下, 本稿では曲げ圧縮破壊する耐震壁の曲げ 変形性能に壁板端部の拘束域の構造詳細が与える影響について実験 的に検討した結果について報告する。なお，本稿で紹介する実験結
* 豊橋技術科学大学大学院工学研究科 大学院生

** 大阪大学大学院工学研究科 准教授 $\cdot$ 博士 (工学)

*** 建築研究所国際地震工学センター 研究員・博士 (工学)

**** 名古屋工業大学大学院工学研究科 助教 $\cdot$ 博士 (工学)

****** 名古屋工業大学大学院工学研究科 教授. 工博

****** 建築研究所構造研究グループグループ長・工博
Graduate Student, Graduate School of Engineering, Toyohashi University of Technology Assoc. Prof., Graduate School of Engineering, Osaka University, Dr. Eng.

Research Engineer, International Institute of Seismology and Earthquake Engineering, Building Research Institute, Dr. Eng.

Assistant Prof., Graduate School of Engineering, Nagoya Institute of Technology, Dr. Eng. Prof., Graduate School of Engineering, Nagoya Institute of Technology, Dr. Eng.

Director, Department of Structural Engineering, Building Research Institute, Dr. Eng. 
果については一部既発表であるが 9), 実験結果の分析方法, 具体的 には変形成分の分離方法に筆者らの最新の知見を反映させて議論す るため, 一部の結果については再掲する方針とした。

以上に加えて, 本稿では先行研究 ${ }^{8)}$, 9)を含む計 13 体の耐震壁の実 験結果を対象に, 曲げ圧縮破壊する耐震壁の曲げ変形性能と強い相 関がある壁板端部の拘束域の構造因子, 寸なわち本構造の変形性能 評価に資する指標の抽出を試みる。国内外の基準で用いられる指標 や, 筆者らが提示する指標について, 曲げ変形性能との相関を分析 した結果について報告する。

\section{2. 壁板端部拘束域の構造詳細を変動因子とする試験体と実験計画 \\ 2.1 試験体}

本研究で用いた試験体の断面図を図 1 に示す。試験体はNM3, C, $\mathrm{N}, \mathrm{N}(\mathrm{s} 70), \mathrm{N}(\mathrm{M} / \mathrm{Qd} 3.1)$ の 5 体で, 試験体 NM3 は先行研究 8)で, 試 験体 C, N は先行研究 9)で既報の試験体である。試験体 C, N は NM3 を基準とし,試験体 $\mathrm{N}(\mathrm{s} 70), \mathrm{N}(\mathrm{M} / \mathrm{Qd} 3.1)$ は $\mathrm{N}$ を基準とし計画された。 スケールは $1 / 2.5$, 壁高さが $1200 \mathrm{~mm}$ である。図 1(a)の試験体 NM3 の配筋図を図 2 に示寸。各試験体の壁板端部拘束域の拡大図を図 3 に，壁板端部拘束域の配筋詳細を図 4 に示す。

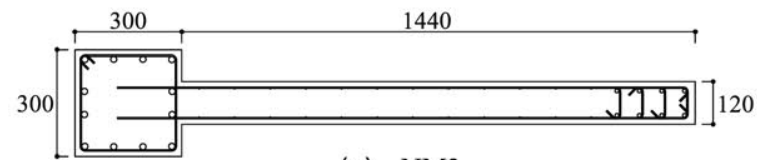

(a) NM3

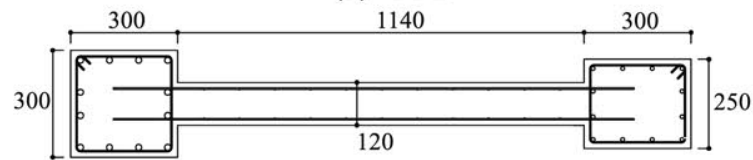

(b) $\mathrm{C}$

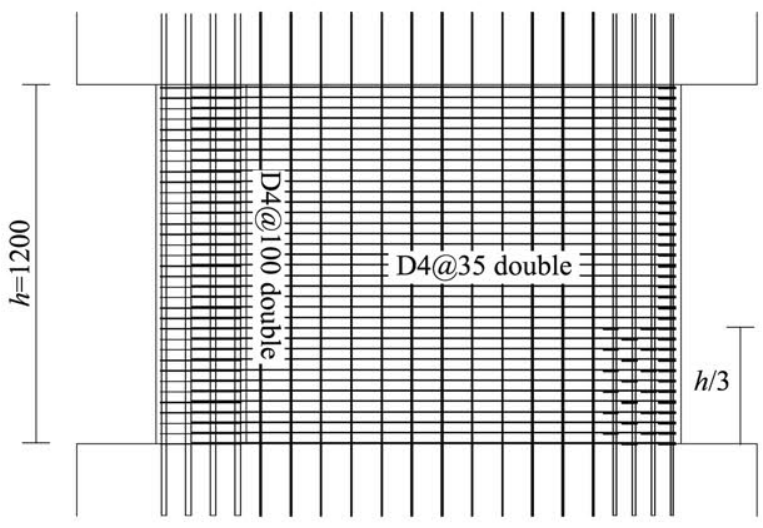

図 2 配筋図(NM3)

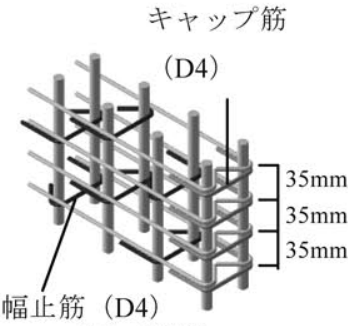

(a) NM3

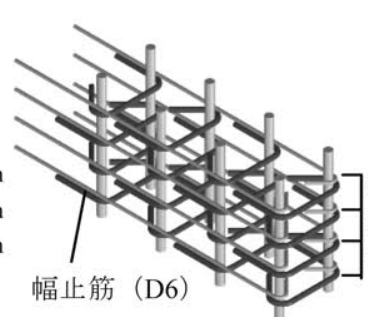

(b) $\mathrm{N}$

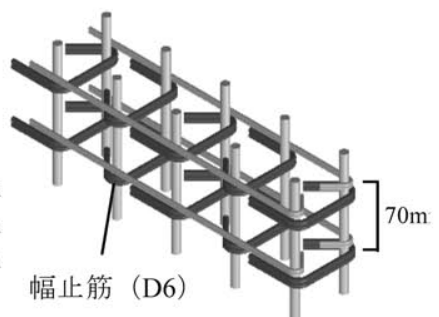

(c) $\mathrm{N}(\mathrm{s} 70)$
試験体の変動因子は表 1 の通りである。試験体 C は試験体 NM3 の壁板端部に RC 規準 $(1999)^{3)}$ の推奨条件を満たす柱型を設けた試 験体である。また試験体 NM3 の壁板端部拘束域長さが同端部から 中立軸までの長さ (以下, 中立軸長さ) の半分程度であるのに対し, 試験体 N では拘束域長さを中立軸長さと同程度とした。中立軸長さ の算定式は文献 9)より下記の式(1)を使用した。

$$
x_{n}=\frac{N+\sum a_{t} \sigma_{y}-\sum a_{c} \sigma_{y}}{0.85 \beta f^{\prime}{ }^{\prime} t}
$$

ここで, $x_{n}$ : 圧縮縁からの中立軸長さ, $N$ : 軸力, $a_{t}, a_{c}$ : 引張, 圧縮 鉄筋断面積, $\sigma_{y}$ : 鉄筋降伏強度, $\beta: \operatorname{ACI} 318^{10}$ による低減係数, $f_{c}^{\prime}$ : コンクリート強度, $t$ : 壁厚(試験体 $\mathrm{C}$ のみ柱幅を代入)である。 なお本研究における壁板端部拘束域長さは式(2)の通り定義する。

$$
l_{c}=a+2 x
$$

ここで, $l_{c}$ : 壁端部拘束域長さ, $a$ : 拘束域端部主筋の外縁間距離（図 3), $x$ : かぶり厚さ（図 3) である。

試験体 NM3 は両方が $90^{\circ}$ フックの D4 キャップ筋を壁端部に配筋 し, 片方が $90^{\circ}$ フック，もう一方が $135^{\circ}$ フックの D4 幅止筋を図 4(a) のように千鳥配筋した。試験体 N は片方が $90^{\circ}$ フック，もう一方が $135^{\circ}$ フックの D6 幅止筋を図 4(b)に示すように $35 \mathrm{~mm}$ 間隔で配筋し
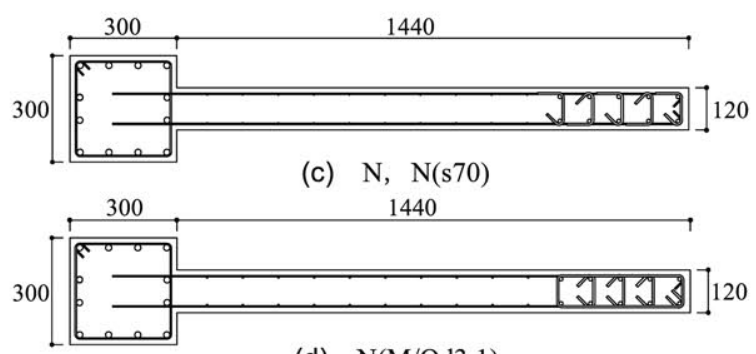

(d) $\mathrm{N}(\mathrm{M} / \mathrm{Qd} 3.1)$

図 1 断面図

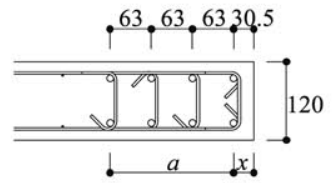

(a) NM3

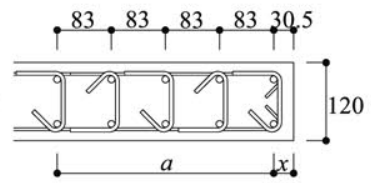

(c) $\mathrm{N}, \mathrm{N}(\mathrm{s} 70)$

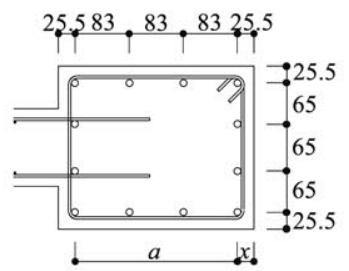

(b) $\mathrm{C}$

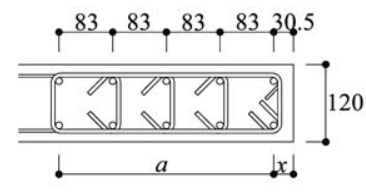

(d) $\mathrm{N}(\mathrm{M} / \mathrm{Qd} 3.1)$

図 3 端部拘束域の拡大図

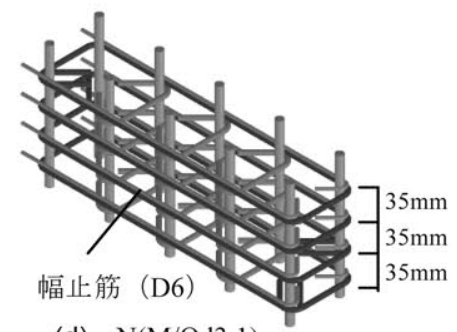

(d) $\mathrm{N}(\mathrm{M} / \mathrm{Qd} 3.1)$

図 4 端部配筋詳細 
表 1 試験体一覧

\begin{tabular}{|c|c|c|c|c|c|c|c|c|c|c|c|c|c|}
\hline \multirow{3}{*}{ 試験体 } & \multicolumn{6}{|c|}{ 変動因子 } & \multicolumn{7}{|c|}{ 構造詳細 } \\
\hline & \multirow{2}{*}{$\begin{array}{l}\text { 端部 } \\
\text { 柱型 }\end{array}$} & \multirow{2}{*}{$\begin{array}{c}\text { 拘束域 } \\
\text { 長さ } \\
(\mathrm{mm})\end{array}$} & \multirow{2}{*}{$\begin{array}{l}\text { 壁横筋 } \\
\text { 間隔 } \\
(\mathrm{mm})\end{array}$} & \multirow{2}{*}{$\begin{array}{c}\text { 拘束䈃 } \\
\text { 間隔 } \\
(\mathrm{mm})\end{array}$} & \multirow{2}{*}{$\begin{array}{c}\text { シア } \\
\text { スパン } \\
\text { 比 }\end{array}$} & \multirow{2}{*}{$\begin{array}{c}\text { 端部 } \\
\text { 筇 } \\
\text { 形状 }\end{array}$} & \multicolumn{2}{|c|}{ 柱 } & \multirow{2}{*}{$\begin{array}{c}\text { 壁板 } \\
\text { 縦筋 } \\
\text { (縦筋比) }\end{array}$} & \multicolumn{4}{|c|}{ 壁板端部拘束域 } \\
\hline & & & & & & & $\begin{array}{l}\text { 主筋 } \\
\text { (主筋比) }\end{array}$ & $\begin{array}{c}\text { 带筋 } \\
\text { (帯筋比) }\end{array}$ & & 主筋 & $\begin{array}{l}\text { 補強筋比 } \\
\text { (長さ方向) }\end{array}$ & $\begin{array}{l}\text { 補強筋比 } \\
\text { (幅方向) }\end{array}$ & $\begin{array}{l}\text { 拘束域 } \\
\text { 高さ }\end{array}$ \\
\hline NM3 & 無 & $0.5 x_{n}$ & 35 & 70 & 1.5 & \multirow{5}{*}{$\begin{array}{l}\text { 図 } 3 \\
\text { 参照 }\end{array}$} & \multirow{5}{*}{$\begin{array}{l}\text { 12-D16 } \\
(2.65 \%)\end{array}$} & \multirow{5}{*}{$\begin{array}{l}\text { D4@35 } \\
(0.27 \%)\end{array}$} & \multirow{5}{*}{$\begin{array}{c}\text { D4@100 } \\
\text { Double } \\
(0.23 \%)\end{array}$} & 8-D10 & $0.67 \%$ & $0.32 \%$ & $1 / 3 \mathrm{~h}$ \\
\hline $\mathrm{C}$ & 有 & $1.5 x_{n}$ & 35 & 35 & 1.5 & & & & & 12-D10 & $0.32 \%$ & $0.27 \%$ & \multirow{4}{*}{$\mathrm{h}$} \\
\hline $\mathrm{N}$ & 無 & $x_{n}$ & 35 & 35 & 1.5 & & & & & 10-D10 & $0.67 \%$ & $1.09 \%$ & \\
\hline $\mathrm{N}(\mathrm{s} 70)$ & 無 & $x_{n}$ & 70 & 70 & 1.5 & & & & & 10-D10 & $0.67 \%$ & $1.09 \%$ & \\
\hline $\mathrm{N}(\mathrm{M} / \mathrm{Qd} 3.1)$ & 無 & $x_{n}$ & 35 & 35 & 3.1 & & & & & 10-D10 & $2.17 \%$ & $1.09 \%$ & \\
\hline
\end{tabular}

た。試験体 $\mathrm{N}(\mathrm{s} 70)$ は試験体 $\mathrm{N}$ と同様の幅止筋を 2 本ずつ束ね図 4(c) に示すように $70 \mathrm{~mm}$ 間隔で配筋した。なお壁横筋も 2 本ずつ束ね $70 \mathrm{~mm}$ 間隔で配筋した。試験体 N(M/Qd3.1)は閉鎖型の D6 拘束筋と 両方が $135^{\circ}$ フックの D6 幅止筋を図 4(d)に示すように配筋した。

後述するように, 試験体 N(M/Qd3.1)以外の試験体ではシアスパン 比が 1.5 となるように, 試験体 N(M/Qd3.1)では約 2 倍の 3.1 となる ように載荷計画を立案した。

使用したコンクリートと鉄筋の材料特性をそれぞれ表 2 および表 3 に示す。

\section{2 実験方法}

加力装置を図 5 に示す。実験は壁板（C では柱型）が正載荷のと きに圧縮, 負載荷のときに引張となるように加力を行った。軸力は 柱中心に負荷した。軸力比は柱断面に対し $0.2(540 \mathrm{kN})$ とした。試験 体 $\mathrm{N}(\mathrm{M} / \mathrm{Qd} 3.1)$ 以外の水平荷重載荷位置は危険断面から $2525 \mathrm{~mm}$ 上方 であり, 柱芯でのシアスパン比は 1.5 である。試験体 N(M/Qd3.1)の 水平荷重載荷位置は危険断面から $5446 \mathrm{~mm}$ 上方となるよう鉛直ジャ ッキにより付加モーメントを作用させた。同試験体の柱芯でのシア スパン比は 3.1 である。載荷サイクルを図 6 に示す。同図の変形角 は, 柱芯頂部 (図 5 中の変位計測位置) の変位を壁高さで除して算 出した。載荷は変位制御による正負交番繰り返し載荷とした。但し, 載荷の第一サイクルは RC 規準 ${ }^{1}$ に従って算出した短期許容応力度 時の水平荷重を与えた。

\section{3. 実験結果とその分析}

\section{1 破壊経過の概要}

図 7 に各試験体の荷重変形関係と最終破壊状況を示す。すべての 試験体に共通して正側で曲げ圧縮破壞して耐力が低下した．本稿で は曲げ圧縮破壊する耐震壁の変形性能に焦点を当てているため, 以 下では正側載荷時のみの実験結果について議論する。同図では正側 の水平荷重が最大耐力の $80 \%$ まで低下した時の変形角を○で示して あり, 本研究ではこの時の変形角を限界変形角と定義する。なお, 試験体 NM3 の実験結果は文献 8)で, 試験体 C, N の実験結果は文 献 9)で既に報告しているが, 比較に必要な情報を本稿でも示す。以 下では試験体 NM3 の破壊経過を報告し, 試験体 C, N の破壊経過に ついては試験体 NM3 の破壊経過と異なる点を, 試験体 N(s70), $\mathrm{N}(\mathrm{M} / \mathrm{Qd} 3.1)$ については試験体 $\mathrm{N}$ と異なる点を報告する。

\section{(1) 試験体 NM3}

柱に曲げひび割れが発生した後,ひび割れが水平に進展していき, 壁には曲げせん断ひび割れが発生した。さらに変形を進めると, 壁 板端部拘束域の脚部に圧縮ひび割れが発生した。その後, 変形角
表 2 コンクリート圧縮試験結果

\begin{tabular}{c|c|c}
\hline \multirow{2}{*}{ 試験体 } & 圧縮強度 & 弾性係数 \\
\cline { 2 - 3 } & $\mathrm{N} / \mathrm{mm}^{2}$ & $\times 10^{3} \mathrm{~N} / \mathrm{mm}^{2}$ \\
\hline $\mathrm{NM} 3$ & 38.3 & 28.4 \\
\hline $\mathrm{C}, \mathrm{N}$ & 45.3 & 31.8 \\
\hline $\mathrm{N}(\mathrm{s} 70)$ & 42.6 & 30.7 \\
\hline $\mathrm{N}(\mathrm{M} / \mathrm{Qd} 3.1)$ & 38.9 & 31.9 \\
\hline
\end{tabular}

表 3 鉄筋引張試験結果

\begin{tabular}{c|c|c|c|c}
\hline \multirow{2}{*}{ 試験体 } & \multirow{2}{*}{ 呼名 } & 降伏応力 & 引張強度 & 弾性係数 \\
\cline { 2 - 5 } & & $\mathrm{N} / \mathrm{mm}^{2}$ & $\mathrm{~N} / \mathrm{mm}^{2}$ & $\times 10^{3} \mathrm{~N} / \mathrm{mm}^{2}$ \\
\hline \multirow{3}{*}{ NM3 } & D4 & 390 & 521 & 173 \\
\cline { 2 - 5 } & D10 & 391 & 469 & 199 \\
\cline { 2 - 5 } & D16 & 389 & 559 & 180 \\
\hline \multirow{4}{*}{ C, N } & D4 & 381 & 515 & 160 \\
\cline { 2 - 5 } & D6 & 393 & 571 & 166 \\
\cline { 2 - 5 } & D10 & 375 & 501 & 161 \\
\cline { 2 - 5 } & D16 & 391 & 569 & 167 \\
\hline \multirow{4}{*}{$\begin{array}{c}\text { N(s70) } \\
\text { N(M/Qd3.1) }\end{array}$} & D4 & 395 & 549 & 180 \\
\cline { 2 - 5 } & D6 & 425 & 521 & 166 \\
\cline { 2 - 5 } & D10 & 376 & 553 & 166 \\
\cline { 2 - 5 } & D16 & 397 & 565 & \\
\hline
\end{tabular}

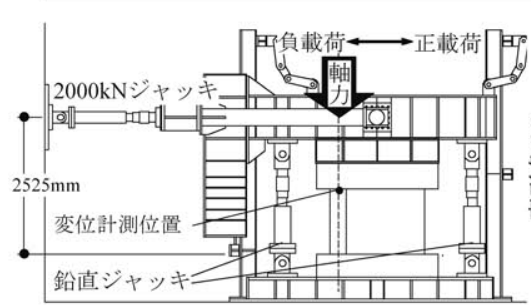

図 5 加力装置

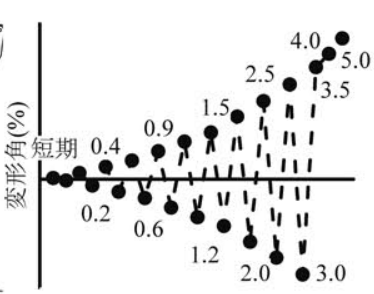

図 6 載荷サイクル
$1.2 \%$ のイクルで拘束域脚部が圧縮破壊することで急激に耐力が 低下した。またこのとき拘束域脚部の主筋の座屈が観られた。壁板 の圧縮破壊が進展した後も一定の水平荷重を保持したまま変形が進 んだ。最終破壊状況における壁板端部コンクリートの剥落高さは $300 \mathrm{~mm}$ 程度であった。

\section{(2) 試験体 C}

壁に曲げひび割れが発生した後, 壁脚部のひび割れに沿って滑り が生じた。なお，本節で対象とする NM3 以外の試験体では壁脚部 にコンクリート打継面を有するため (NM3 は壁面が水平な状態でス タブと一体に打設した), 同様の滑りが観られた。柱型を有する本試 験体では変形角 $2.0 \%$ のイクルで柱型内の主筋の座屈によると考 えられるカバーコンクリートの膨らみが確認され, 変形角 $2.5 \%$ のサ イクルで当該主筋の座屈が目視で確認された。その後, 壁脚の圧縮 破壊が進行したが, 柱型内の主筋座屈後も耐力低下は穏やかであり 耐力を即座に喪失することなく優れた変形性能を示した。最終破壊 
状況における圧縮側柱型の剥落高さは $200 \mathrm{~mm}$ 程度, 柱型と壁板境 界の剥落高さは $300 \mathrm{~mm}$ 程度であった。

(3) 試験体 N

変形角 $2.5 \%$ のイクルで壁板端部の拘束域脚部の主筋座屈, 幅止 筋の $90^{\circ}$ フックの開きを確認した。変形角 $3.0 \%$ のサイクルで拘束域 脚部が圧縮破壊寸るとともに耐力が低下した。本試験体の拘束域の 長さと幅止筋比は試験体 NM3 の約 2 倍であり変形性能が向上した。

\section{（4）試験体 N (s70)}

本試験体は試験体 $\mathrm{N}$ の拘束域幅止筋と壁横筋を 2 本ずつ束ねて配 筋した試験体である。試験体 N では変形角 $2.5 \%$ のサイクルで幅止 筋 $90^{\circ}$ フックの開きが確認されたが, $\mathrm{N}(\mathrm{s} 70)$ では同サイクルにおいて 同フックの開きは確認されなかった。幅止筋を束ねたことで，フッ クの開きに対する抵抗が増した可能性がある。本試験体は変形角 $3.0 \%$ のイクルで壁脚部が拘束域の主筋座屈を伴って圧縮破壊し
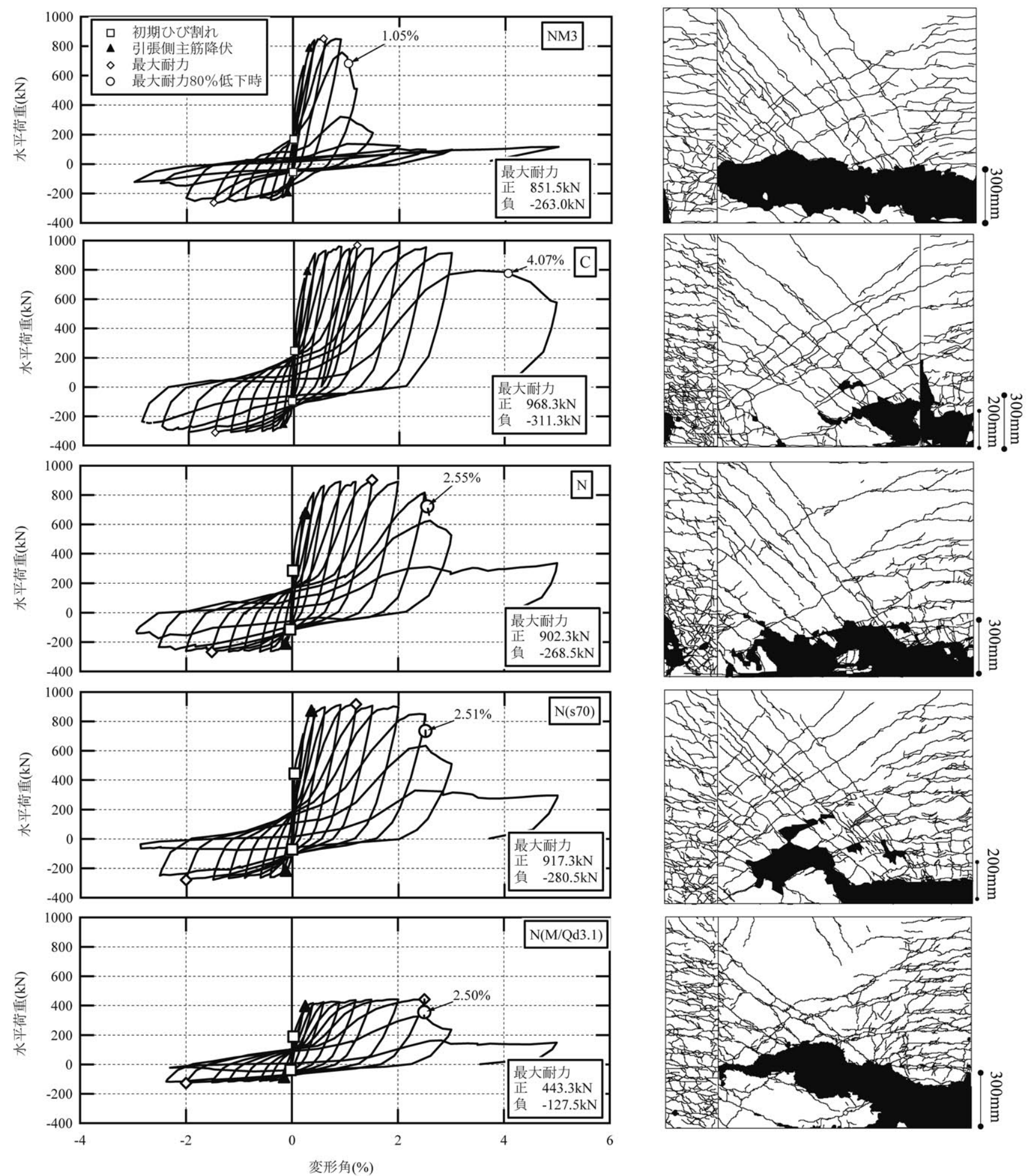

図 7 荷重変形関係, 最終破壞状況 
耐力低下した。最終破壊状況における壁端部コンクリートの剥落高 さは $200 \mathrm{~mm}$ 程度であった。

\section{(5) 試験体 N(M/Qd3. 1)}

変形角 $3.0 \%$ のイクルで端部主筋が座屈し, 耐力が低下した。主 筋の座屈（壁脚の曲げ圧縮破壊）後に閉鎖型拘束筋の端部 $135^{\circ}$ フッ クの開きが確認された。

\section{2 曲げ変形の分離方法}

上記のように曲げ圧縮破壊した耐震壁の変形性能, とくに曲げ変 形性能について精緻に分析するため, 本稿では曲げ変形性能を抽出 して比較する。

はじめに本実験において限界変形時に壁脚部断面が平面保持され ていたか検討する。図 8 に耐震壁各部の軸方向変形計測用の変位計 配置を示寸。変位計 ET1〜3, WT1～3 は壁両端, NT1～3 は式(1)に より評価した中立軸位置での壁高さを 3 分割した計測区間各 $400 \mathrm{~mm}$ における軸方向変形を測定している。壁脚部の ET3, NT3, WT3 の 変形を歪に換算し, 例として試験体 N(M/Qd 3.1$)$ の正載荷における変 形角 $2.5 \%$ 時の断面方向歪分布を図 9 に示寸。同図に示寸通り E-N 間と $\mathrm{N}-\mathrm{W}$ 間で曲率が異なっている。よって, 平面が保持されていな いと判断される。同様の傾向は他の試験体でも確認された。なお, この傾向は圧縮側壁脚部において圧縮ひび割れ発生後に顕著に観ら れた。

続いて, 各試験体の曲げ変形を抽出する。平石の方法 ${ }^{11)}$ を参考に, 図 8 の NT1 3,WT1 3の 6つの変位計から算出した 3 点の回転角 $\theta_{\mathrm{b}}$, $\theta_{\mathrm{m}}, \theta_{\mathrm{t}}$ に基づき, 図 10 のように回転角の高さ方向の分布を仮定し, それを積分することにより曲げ変形を算出した。曲げ変形の算出を $\mathrm{N}-\mathrm{W}$ 間で行った理由は, 図 9 で示した通り断面の平面保持が成立し ておらず，とくに曲げ変形性能に関する議論ではその性能を決定し たコンクリートの圧壊が生じた領域で評価するのが妥当と判断した ためである。なお, 参考に N-W 間での評価では E-W 間での評価と 比較して, 壁脚部の曲率が大きく評価されるため (図 9 参照), 曲げ
変形成分を大きく評価する傾向があった。その誤差は試験体ごとに ばらつきがあるが平均的に $20 \%$ 程度であった。

\section{3 拘束域の構造詳細が曲げ変形性能に与える影響}

水平荷重と上記の方法で抜き出した曲げ変形成分の関係を図 11 に示す。水平荷重が正側で最大耐力の $80 \%$ まで低下した時の曲げ変 形角を図中に。で示してあり, 本研究ではこの変形角を限界曲げ変 形角と定義する。

圧縮側端部に柱型を設けた試験体 C の限界曲げ変形角は柱型のな い試験体 NM3 に比べて 2.4 倍大きい。また試験体 NM3 に比べ端部 の拘束域長さ（主筋量, 拘束筋量を含む）を大きくした試験体 $\mathrm{N}$ の 限界曲げ変形角は 1.4 倍大きい。圧縮側端部に柱型を設ける，また は端部の拘束域長さ（主筋量, 拘束筋量を含む）を大きくする, す なわち拘束域断面積を大きくすることで曲げ変形性能が向上するこ とを確認した。なお試験体 NM3 と試験体 $\mathrm{N}$ は拘束域高さが異なっ ているが，図 7 に示すように最終破壊状況における端部コンクリー 卜の剥落高さ, すなわち両試験体の圧縮ヒンジ長さは同程度となっ たことから，拘束域高さは拘束域高さ>ヒンジ長さの条件下で変形 性能に影響しなかったと判断される。

試験体 $\mathrm{N}(\mathrm{s} 70)$ の壁横筋と端部拘束筋は 2 段ごとに束ねて配筋され, その結果，配筋間隔は試験体 $\mathrm{N}$ の 2 倍である。前述のように, 試験 体 $\mathrm{N}(\mathrm{s} 70)$ では幅止筋のフックの開きが生じず，限界曲げ変形角は試 験体 $\mathrm{N}$ に対し 1.5 倍であった。

試験体 $\mathrm{N}(\mathrm{M} / \mathrm{Qd} 3.1)$ は試験体 $\mathrm{N}$ の端部拘束筋を閉鎖型としシアス パン比を約 2 倍にした試験体である。シアスパン比を大きくしたこ とで試験体 N(M/Qd3.1)に作用するせん断力は試験体 $\mathrm{N}$ の半分程度 であった。これらの効果により, 試験体 N(M/Qd3.1)の限界曲げ変 形角は試験体 $\mathrm{N}$ の 2 倍まで向上した。

\section{4. 拘束域の構造因子と曲げ変形性能の相関}

曲げ圧縮破壊する耐震壁の壁板端部拘束域の構造因子が曲げ変形

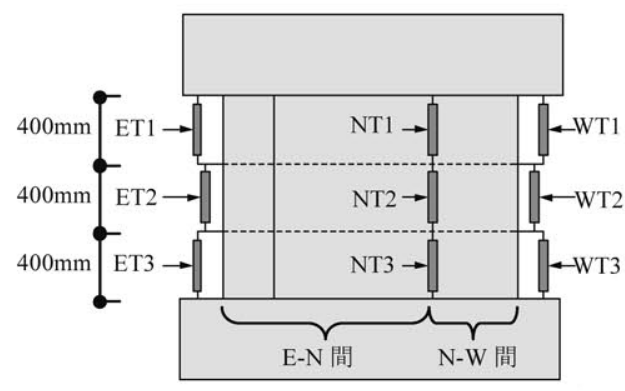

図 8 変位計位置

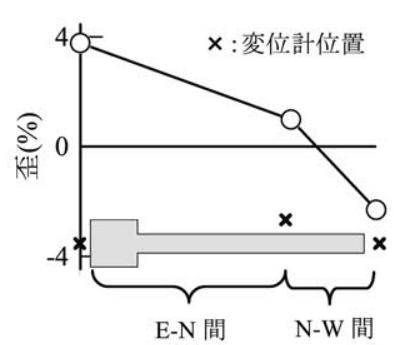

図 $9 \mathrm{~N}(\mathrm{M} / \mathrm{Qd} 3.1)$ $\mathrm{R}=2.5 \%$ 時脚部歪分布

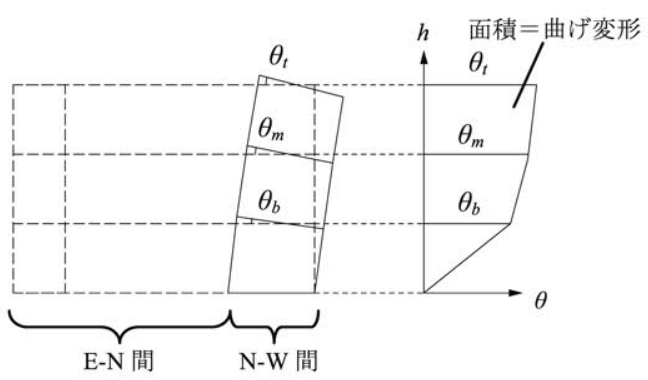

図 10 曲げ変形算出方法
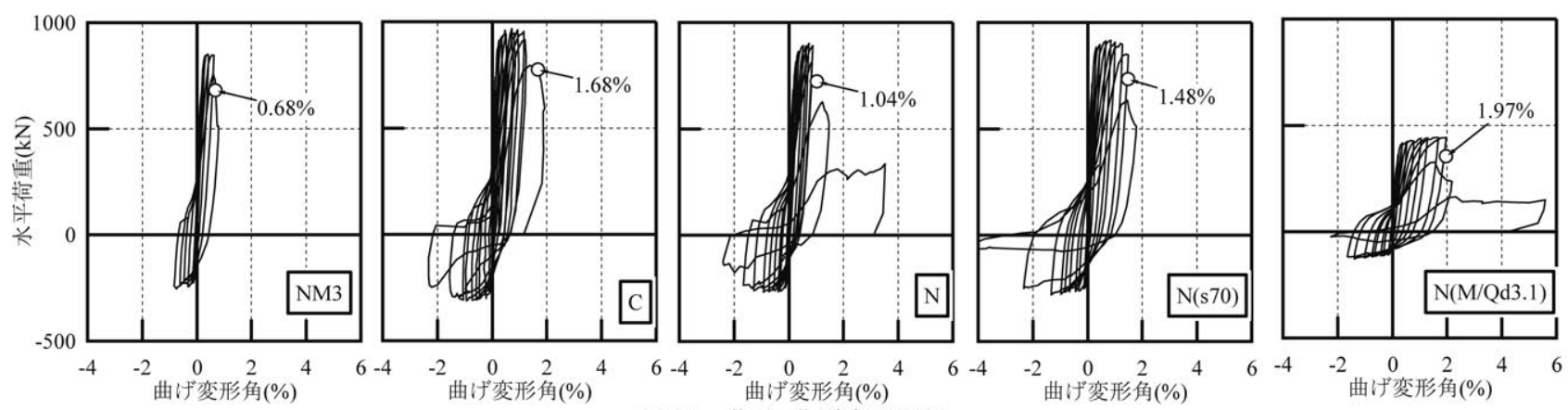

図 11 荷重-曲げ変形関係 
表 4 試験体一覧

\begin{tabular}{|c|c|c|c|c|c|c|c|c|c|c|c|c|c|c|c|c|}
\hline \multirow{3}{*}{ 試験体名 } & \multirow{3}{*}{ Type } & \multirow[b]{2}{*}{ 軸力 } & \multirow[b]{2}{*}{ 全せい } & \multirow[b]{2}{*}{ 壁高さ } & \multicolumn{4}{|c|}{ 柱 } & \multicolumn{2}{|c|}{ 壁 } & \multicolumn{4}{|c|}{ 壁板端部拘束域 } & \multicolumn{2}{|c|}{ 限界変形角 } \\
\hline & & & & & $\mathrm{b}, \mathrm{D}$ & 主筋 & 補強筋 & 壁厚 & 横筋※ & 縦筋※ & $\begin{array}{c}\text { 拘束域 } \\
\text { 高さ }\end{array}$ & $\begin{array}{c}\text { 拘束域 } \\
\text { 長さ }\end{array}$ & 主筋 & 拘束筋 & 曲げ & 全体 \\
\hline & & $\mathrm{kN}$ & $\mathrm{mm}$ & $\mathrm{mm}$ & $\mathrm{mm}$ & - & - & $\mathrm{mm}$ & - & - & $\mathrm{mm}$ & $\mathrm{mm}$ & - & - & $\%$ & $\%$ \\
\hline NM4 & \multirow{10}{*}{$\mathrm{N}$} & 0 & 1400 & \multirow{2}{*}{1000} & \multirow{2}{*}{300} & \multirow{2}{*}{ 12-D16 } & \multirow{14}{*}{ D4@35 } & 94 & \multirow{8}{*}{ D4@35 } & \multirow{14}{*}{ D4@100 } & 400 & 250 & 8-D10 & D4@35 & 0.80 & 1.50 \\
\hline NM5 & & 400 & 1400 & & & & & 94 & & & 400 & 250 & 8-D10 & D4@35 & 0.59 & 0.83 \\
\hline NL2 & & 240 & 2000 & \multirow{12}{*}{1200} & 200 & 8-D13 & & 100 & & & 400 & 250 & $8-\mathrm{D} 10$ & D4@70*2 & 1.36 & 2.30 \\
\hline NS3 & & \multirow{11}{*}{540} & 1020 & & \multirow{11}{*}{300} & \multirow{11}{*}{ 12-D16 } & & 120 & & & 400 & 250 & $8-\mathrm{D} 10$ & D4@70*2 & 1.11 & 1.33 \\
\hline NM3 & & & 1740 & & & & & 120 & & & 400 & 250 & 8-D10 & D4@70*2 & 0.68 & 1.05 \\
\hline NM2 & & & 1980 & & & & & 140 & & & 400 & 250 & $8-\mathrm{D} 10$ & D4@70\%2 & 0.95 & 1.60 \\
\hline NM2' & & & 1740 & & & & & 140 & & & 400 & 250 & 8 -D10 & $※ 4$ & 0.69 & 1.20 \\
\hline $\mathrm{N}$ & & & 1740 & & & & & 120 & & & 1200 & 393 & $10-\mathrm{D} 10$ & D6@35*3 & 1.04 & 2.55 \\
\hline $\mathrm{N}(\mathrm{s} 70)$ & & & 1740 & & & & & 120 & D4@70 & & 1200 & 393 & 10-D10 & D6@70※3 & 1.48 & 2.51 \\
\hline $\mathrm{N}(\mathrm{M} / \mathrm{Qd} 3.1)$ & & & 1740 & & & & & 120 & \multirow{5}{*}{ D4@35 } & & 1200 & 393 & 10-D10 & D6@35* & 1.97 & 2.50 \\
\hline PM3 & \multirow{3}{*}{$\mathrm{P}$} & & 1740 & & & & & 120 & & & 400 & 250 & $8-\mathrm{D} 10$ & D4@70\% & 0.62 & 1.40 \\
\hline PM5 & & & 1500 & & & & & 100 & & & 400 & 250 & $8-\mathrm{D} 10$ & D4@70※2 & 0.66 & 1.02 \\
\hline PL6 & & & 1920 & & & & & 90 & & & 400 & 250 & $8-\mathrm{D} 10$ & D4@70\%2 & 0.51 & 1.01 \\
\hline $\mathrm{C}$ & $\mathrm{C}$ & & 1740 & & & & & 120 & & & 1200 & 300 & 12 -D10 & D4@35 & 1.68 & 4.07 \\
\hline
\end{tabular}

※1: ダブル配筋, ※2 : 図 4(a)参照, ※3, 図 4(b)〜(d)参照, ※4 : 拘束筋無し (キャップ筋のみ)

性能に与える影響を検討する。各試験体の限界曲げ変形角は前述の 定義の通りである。以下の(1) (8)では, 文献 12)を参考とし, ACI318 $18^{10}$ や Eurocode $8^{13}$ に規定がある拘束域の構造因子に関する指標との比 較を行った。但し, 構造因子のみから一義的に数值が決定されない 指標（例えば，設計での目標性能に依存寸る指標など）については 対象外とした。また, わが国の現行の耐震規定 ${ }^{2} に あ る$ 平均せん断 応力度/コンクリート圧縮強度比との比較を(9)で, 文献 8)で提案さ れた壁厚/中立軸長さ比との比較を(10)で行った。さらに(11)では 3 章の実験結果に基づき拘束域の軸力比に着目して比較した。試験体 一覧を表 4 に示す。検討に用いる試験体は先行研究 $\left.{ }^{8)}, 9\right)$ で実験を実施 した試験体に本研究で新たに追加した試験体をあわせた計 13 体(表 4 中の試験体 PM3 を除く) である。試験体 PM3 は図 8 に示す NT 変位計の計測不良により他の試験体と同様に曲げ変形を抽出できな かったことから, 後述する相関係数算出からは除外した。但し, 参 考のため図 14 にET-WT 変位計間 (図 8 参照) で算出した結果を灰 色でプロットした。また, 試験体 NM2'は図 12 に示す通り壁板端部 に幅止筋がない試験体であるため, 同試験体は拘束域がないものと みなした。そこで以下では(9), (10)でのみ検討の対象とした。なお, 表 4 中の各試験体名の頭文字は, 図 13 に示すように, 圧縮側に直交 壁のある試験体が $\mathrm{P}$, 柱型のある試験体が $\mathrm{C}$, それ以外の試験体が Nであることを示している。

\section{(1) 拘束域長さ}

式(3)，(4)に示す $l_{c . A C l}, l_{c . E C S}$ はそれぞれ ACI $318^{10)}$ の而震設計およ び Eurocode $8^{13)}$ の高鞋性な耐震壁の設計で要求される拘束域長さで ある。

$$
\begin{aligned}
& l_{c . A C I}=\max \left(c-0.1 l_{w}, c / 2\right) \\
& l_{c . E C 8}=\max \left(0.15 l_{w}, 1.5 b_{w}\right)
\end{aligned}
$$

ここで, $c$ : 中立軸長さ $\left(=\right.$ 式(1)の $\left.x_{n}\right), l_{w}$ : 試験体の全せい, $b_{w}$ : 拘 束域幅である。

各試験体の拘束域長さ $l_{c}$ (式(2)参照) を $l_{\text {c.ACl }}, l_{\text {c.ECS }}$ でそれぞれ除 した值を横軸に, 限界曲げ変形角を縦軸にとった関係を図 14(a), (b) に示す。前者には比較的強い正の相関が観られたが, 後者には相関 が観られなかった。式(3)より， $l_{c, A C l}$ は主に中立軸長さに関連する指 標であり, これが大きいことは断面の圧縮端からの中立軸位置が深 (a) NM2'

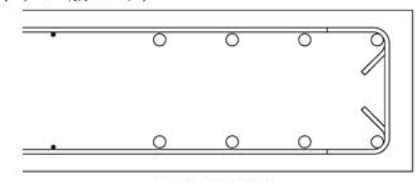

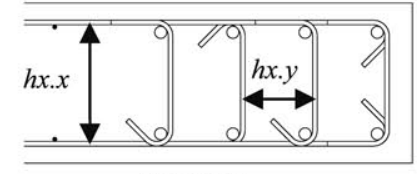

(b) NM2
図 12 NM2', NM2 端部詳細

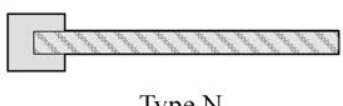

Type $\mathrm{N}$

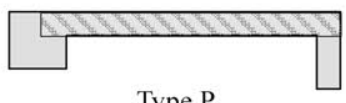

Type P

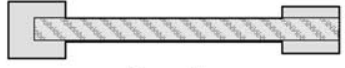

Type C

図 13 断面形状

いことを意味する。ここで圧縮端コンクリートが圧壊する歪が一定 と仮定すると, 中立軸位置が浅い/深いほど圧壊時の曲率は大きく/ 小さくなる。従って, 試験体の拘束域長さの効果のみならず, $l_{\text {c.ACl }}$ が小さいほど（中立軸深さが浅いほど）, 曲げ変形性能が増大寸る と解釈できる。一方, 式(4)より表 4 の試験体はNS3 を除くすべての 場合に $l_{c . E C 8}$ は壁長さに関連する指標であるため, 曲げ変形性能と壁 長さには物理的な関係が希薄であることを意味しており，筆者らの 文献 8)における実験結果の分析とも整合した。

但し, ACI $318^{(0)}$ と Eurcode $8^{(3)}$ では拘束域長さについて, 式(3), (4) に加え, 設計目標に応じて算定される拘束域コンクリートの圧縮歪 に基づく規定も別途存在することを補足する。

\section{(2) 拘束域幅}

式(5)に示す $b_{w: E C 8}$ は Eurocode $8^{13)}$ で高勒性な耐震壁に要求される 拘束域幅である。

$$
\begin{aligned}
& l_{c} \leq \max \left(2 b_{w}, \frac{l_{w}}{5}\right) \text { の場合, } b_{w . E C 8}=\max \left(200 \mathrm{~mm}, \frac{h_{s t}}{15}\right) \\
& l_{c}>\max \left(2 b_{w}, \frac{l_{w}}{5}\right) \text { の場合, } b_{w . E C 8}=\frac{h_{s t}}{10}
\end{aligned}
$$

ここで, $h_{s t}:$ 壁高さである。

各試験体の拘束域幅を $b_{w E C E}$ で除した值を横軸に, 限界曲げ変形 角を縦軸にとった関係を図 14(c)に示す。但し， $b_{w: E C 8}$ の算定では実 大相当の長さに関する規定について試験体スケールを考慮した。両 者には相関は観られなかった。式(5)より， $b_{w . E C 8}$ は主に細長比が制 限されており, 部材の座屈防止などを目的とする仕様規定と考えら れ, 変形性能と定量的な相関を有する指標ではないと判断される。 


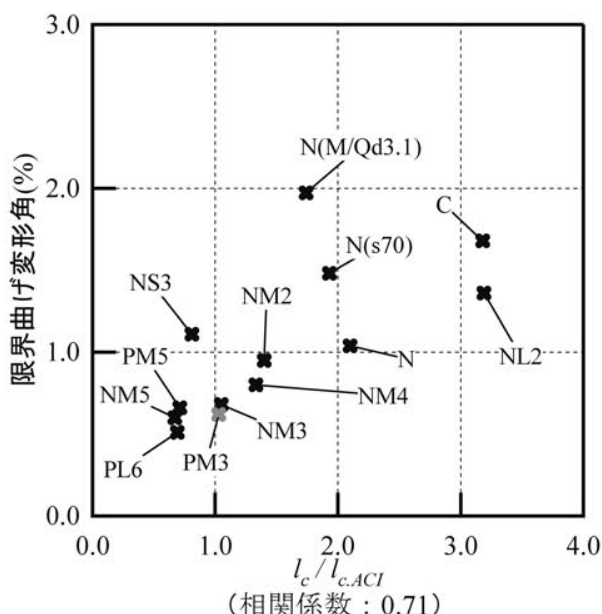

(a) 拘束域長さ(ACI)

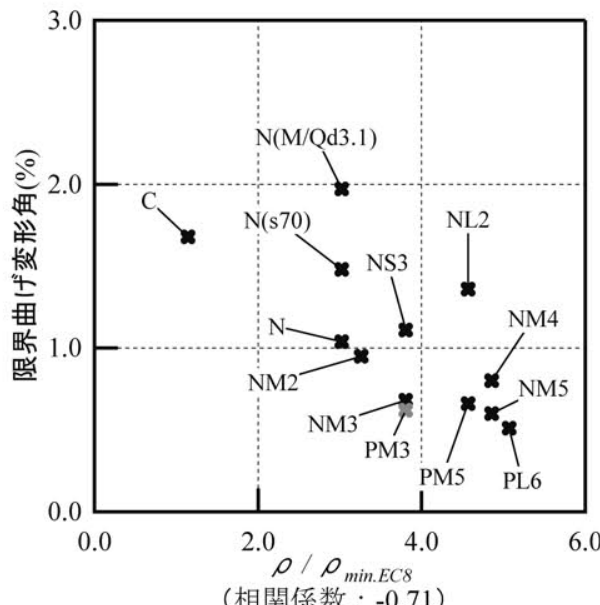

(相関係数 : -0.71$)$

(d) 主筋比

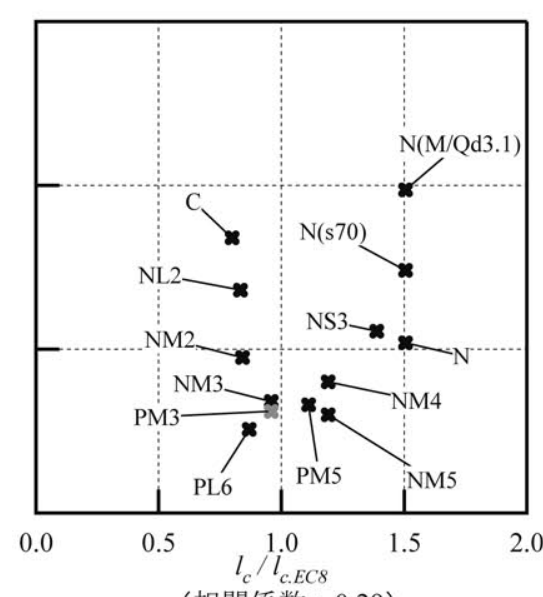

(相関係数 : 0.29)

(b) 拘束域長さ(EC8)

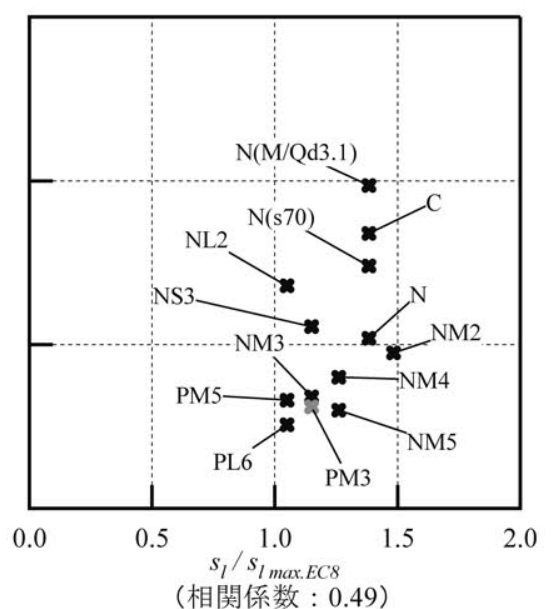

(e) 主筋間隔

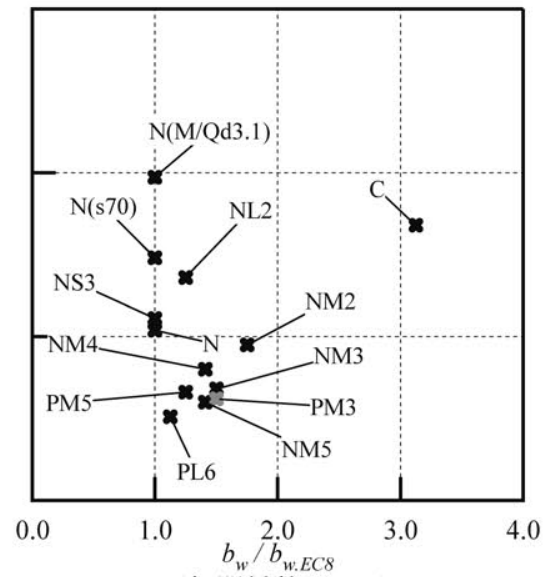

(相関係数 : 0.20

(c) 拘束域幅

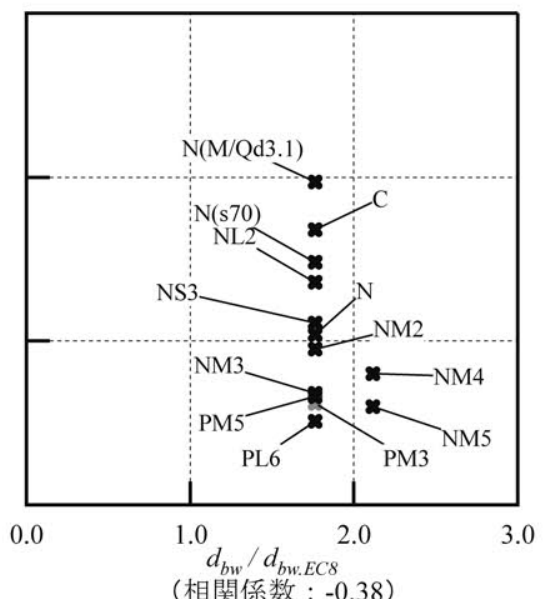

(f) 横補強筋径

図 14-1 拘束域の構造因子と曲げ変形性能の相関

\section{(3) 主筋比}

式(6)に示す $\rho_{E C 8}$ は Eurocode $8^{13)}$ で高勒性な耐震壁に対する拘束域 の主筋比の許容範囲である。

$$
0.005 \leq \rho_{E C 8} \leq 0.04
$$

各試験体の拘束域の主筋比を最小主筋比 $\rho_{\min . E C 8}(=0.005)$ で除し た値を横軸に, 限界曲げ変形角を縦軸にとった関係を図 14(d)に示す。 両者には比較的強い負の相関が観られた。表 4 より, 本稿で報告し た試験体を除く（表 1 参照）既往の試験体では, 壁板端部拘束域の 主筋量が同一である。従って, 壁厚が薄い試験体ほど主筋比が大き くなるため, 主筋比が大きい試験体ほど変形性能が低下する傾向が 表れた可能性がある。

\section{(4) 主筋間隔}

式(7)に示す $s_{l . E C 8}$ は Eurocode $8^{13)}$ で高勒性な耐震壁に要求される主 筋間隔である。

$$
s_{l, E C 8} \leq 150 \mathrm{~mm}
$$

各試験体の拘束域の主筋間隔を最大主筋間隔 $S_{l \max : E C 8}$ (但し, 試験 体スケールを考慮) で除した值を横軸に, 限界曲げ変形角を縦軸に とった関係を図 14(e)に示す。全試験体の主筋間隔に大差がないが,

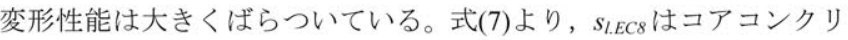
一トに対する拘束効果を保証するための仕様規定と考えられる。コ アコンクリートに対する拘束効果は変形性能に一定の影響を与え得 るが, 他方, 主筋間隔が独立して変形性能と相関を示寸とも考えに くい。同図は主筋間隔と変形性能を直接的に比較しているが, 後述 する横補強筋間隔に関する規定のように，鉄筋径などの構造因子も 複合的に考慮すれば, 両者の相関が改善される可能性を指摘できる。 (5) 横補強筋径

式(8)に示す $d_{b w . E C 8}$ は Eurocode $8^{13)}$ で高勒性な耐震壁に要求される 拘束域の横補強筋径である。

$$
d_{b w . E C 8}=\min \left(6 \mathrm{~mm}, 0.4 d_{b L} \sqrt{\frac{f_{y d}}{f_{y w d}}}\right)
$$

ここで, $d_{b L}$ : 主筋径, $f_{y d}$ : 主筋降伏強度, $f_{y w d}$ : 横補強筋降伏強度で ある。

各試験体の拘束域の横補強筋径を $d_{b w E C S}$ で除した值を横軸に, 限 界曲げ変形角を縦軸にとった関係を図 14(f)に示す。但し， $d_{b w . E C 8}$ の 算定では実大相当の長さに関する規定について試験体スケールを考 慮した。全試験体の横補強筋径に大差がないが，変形性能は大きく ばらついている。式(8)より， $d_{b w . E C 8}$ は主筋との径や鋼材種の違いを 


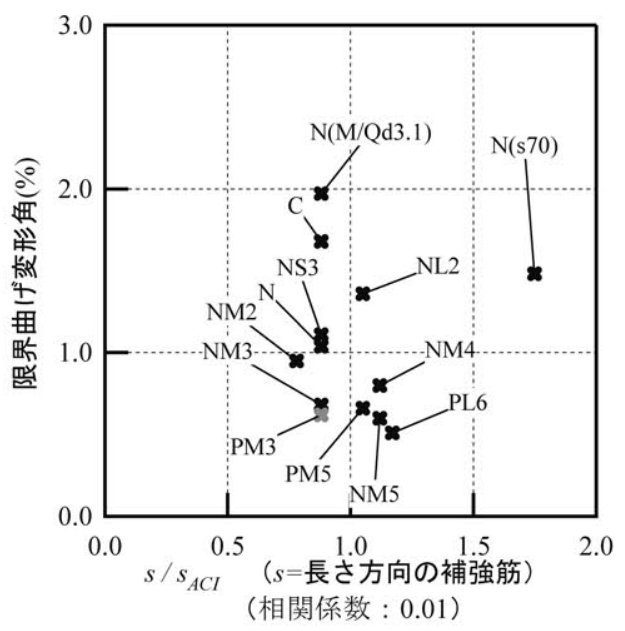

(g) 横補強筋間隔 (長さ方向の補強筋)

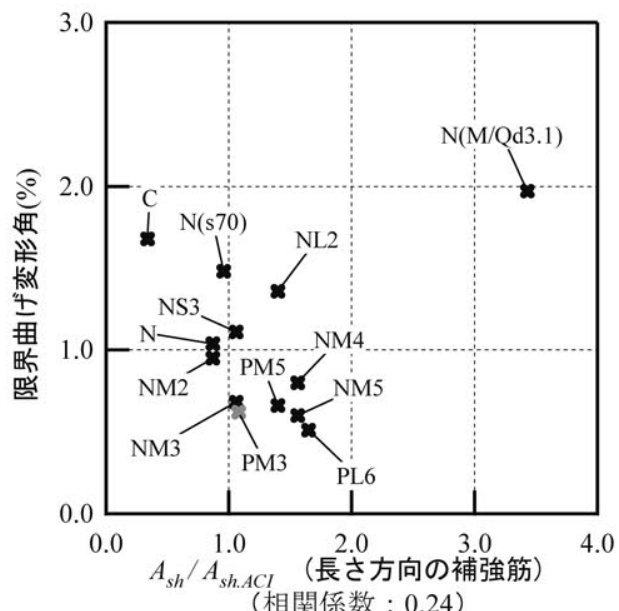

(j) 横補強笳断面積(長さ方向の補強筋)

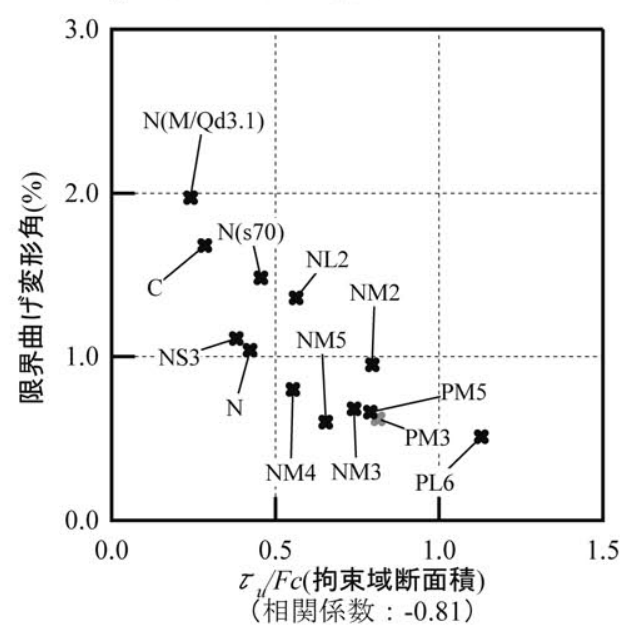

(m) $\tau_{\imath} / F_{c}(A=$ 拘束域断面積 $)$

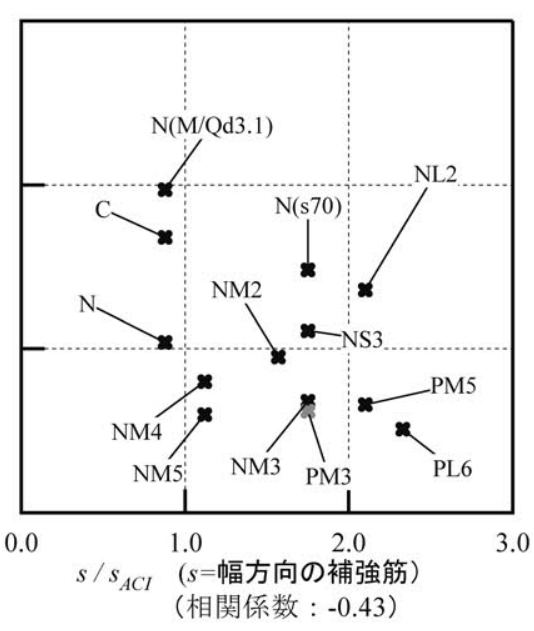

(h) 横補強筋間隔 (幅方向の補強筋)

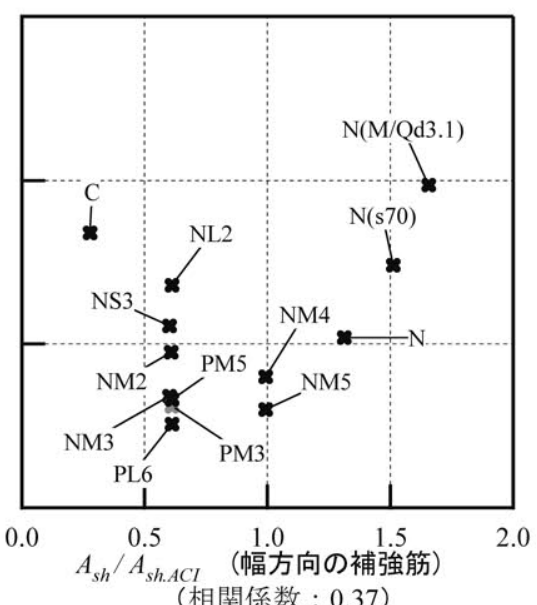

(k) 横補強筋断面積 (幅方向の補強筋)

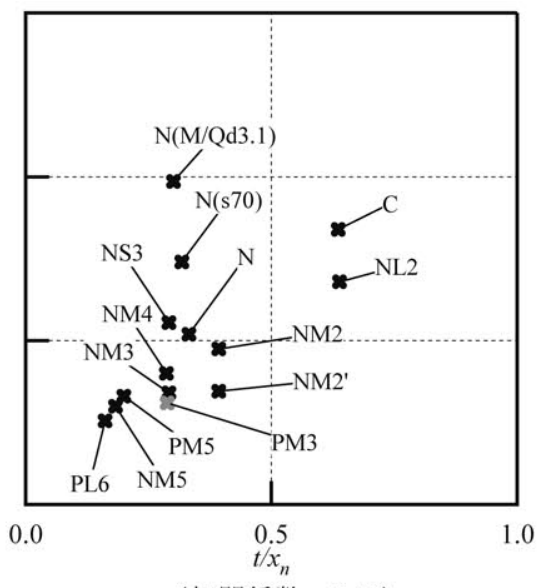

(相関係数 : 0.56$)$

(n) 壁厚/中立軸長さ比

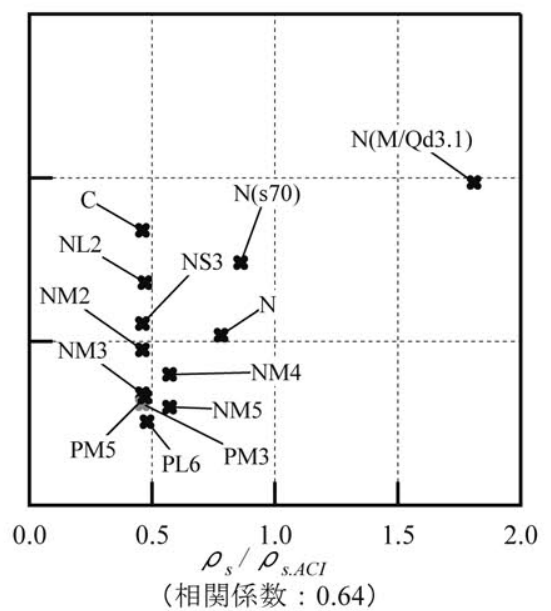

(i) 拘束筋体積比

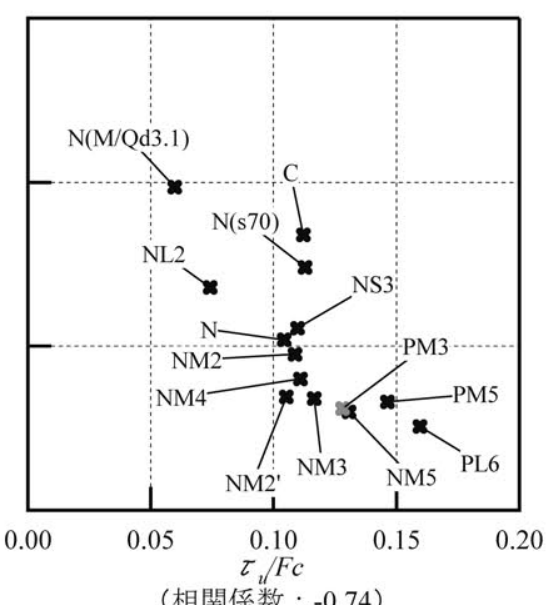

(相関係数 : -0.74$)$

(I) $\tau_{u} / F_{c}$

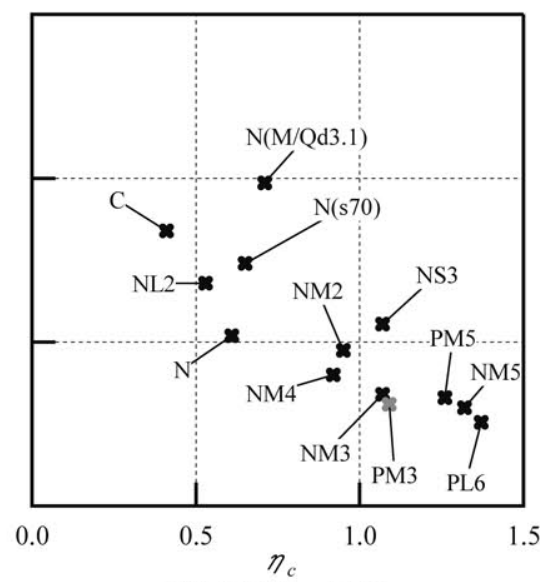

(相関係数 : -0.82$)$

(o) 軸力比

図 14-2 拘束域の構造因子と曲げ変形性能の相関

考慮して横補強筋の最小径を規定する仕様規定であり, 本指標が独 立して曲げ変形と相関を有するとは期待できず, 妥当な結果と判断 される。

\section{(6) 横補強筋間隔}

式(9)に示す $s_{A C I}$ は ACI $318^{10)}$ の耐震設計で要求される横補強筋の 配筋間隔である。なお, Eurocode $8^{13}$ にもおよそ同様の規定が存在す
るがこここで扱う試験体についてはすべて ACI 318 による制限值が Eurocode 8 の制限值以下であった。

$$
s_{A C l}=\min \left(\min \left(\frac{t}{3}, \frac{l_{c}}{3}, \frac{B_{c}}{3}\right), 6 d_{c v}, 100 \leq 100+\left(\frac{350-h_{x}}{3}\right) \leq 150\right)
$$


ここで, $B_{c}$ : 柱幅, $d_{c v}$ : 主筋径 $\left(=d_{b L}\right), h_{x}: \max (h x . x, h x . y), h x . x$, $h x y:$ 図 12 に示寸拘束筋の芯々間距離である。

各試験体の拘束域長さ方向の補強筋の配筋間隔を $s_{A C I}$ で除した值 を横軸に, 限界曲げ変形角を縌軸にとった関係を図 $14(\mathrm{~g})$ に示す。但 し， $s_{A C I}$ の算定では実大相当の長さに関する規定について試験体ス ケールを考慮した。両者に相関は観られなかった。また拘束域幅方 向の補強筋の配筋間隔を $s_{A C I}$ で除した值を横軸に, 限界曲げ変形角 を縦軸にとった関係を図 14(h)に示す。両者には弱い負の相関が観ら れた。一般に横補強筋間隔を密にすると変形性能が向上寸ると考え られている。これは主筋や縦筋の座屈抵抗が増大寸るためと考えら れるが，3 章の実験結果では試験体 $\mathrm{N}(\mathrm{s} 70)$ の壁横筋と端部拘束筋の 配筋間隔を大きくする（束ねて配筋する）ことで幅止筋の $90^{\circ}$ フッ クの開きが抑制され変形性能が向上寸る結果が得られた。従って, $90^{\circ}$ フックの拘束筋が配された耐震壁に限れば, 横補強筋間隔と曲げ 変形性能に一義的な相関を見積もるのは必ずしも適切でないと考え られる。

\section{(7) 拘束筋体積比}

式(10)に示す $\rho_{\text {s.ACI }}$ は $\mathrm{ACI} 318^{10)}$ で要求される拘束筋体積比である。

$$
\rho_{s . A C l}=\max \left(\frac{0.12 f_{c}^{\prime}}{f_{y t}}, 0.45\left(\frac{A_{g}}{A_{c h}}-1\right) \frac{f_{c}^{\prime}}{f_{y t}}\right)
$$

ここで, $f_{y t}$ : 横補強筋の降伏強度 $\left(=f_{y w d}\right), A_{g}$ : かぶりを含む拘束域 断面積 (図 15 中に灰色で示寸部分の面積), $A_{c h}$ : 横補強筋で囲まれ た拘束域断面積 (図 15 中, 黒破線で示した拘束筋外縁に囲まれる面 積）である。

各試験体の拘束筋体積比を $\rho_{\text {s.ACI }}$ で除した值を横軸に, 限界曲げ変 形角を縦軸にとった関倸を図 14(i)に示す。両者にはやや正の相関が 観られた。なお, Eurocode $\left.8^{13}\right)$ には拘束筋体積比を 0.12 ・ (コンクリ 一ト圧縮強度/拘束筋降伏強度)以上と寸る規定があるが, 式(10)によ る $\rho_{\text {s.ACl }}$ はすべての試験体に対しこれを上回った。

\section{（8）横補強筋断面積}

式(11)に示す $A_{s h . A C l}$ は $\mathrm{ACI} 318^{(0)}$ で要求される拘束域内の横補強 筋断面積である。

$$
A_{\text {sh. } A C l}=0.09 \frac{s b_{c} f_{c}^{\prime}}{f_{y t}}
$$

ここで, $b_{c}:$ 図 12 に示す $h x . x, h x . y$ である。

各試験体の拘束域の横補強筋断面積を $A_{s h . A C l}$ で除した值を横軸に, 限界曲げ変形角を縦軸にとった関係を図 14(j)(k)に示す。図 14(j)で は $A_{s h . A C l}$ を拘束域長さ方向の補強筋に対して $\left(b_{c}=h x . x\right)$, 図 14(k)では 幅方向の補強筋に対して $\left(b_{c}=h x . y\right)$ 評価した。拘束域幅方向の補強筋 に対する相関が相対的に高い結果は, 横補強筋間隔に関する分析結 果と整合する。

\section{(9) 平均せん断応カ度/コンクリート圧縮強度比}

わが国の現行の耐震規定 ${ }^{2}$ において耐震壁の部材種別判定の唯一 の指標である $\tau_{u} / F_{c}\left(\tau_{u}\right.$ : 而震壁に生じる平均せん断応力度, $F_{c}:$ コ ンクリートの圧縮強度 $\left.\left(\mathrm{N} / \mathrm{mm}^{2}\right)\right)$ について検討する。 3.3 節で既述の ように本実験においてもシアスパン比を大きくし作用せん断力を小 さくした場合に曲げ変形性能が向上したため, 変形性能と相関があ ることが期待される。

$$
\tau_{u}=\frac{Q_{\max }}{A}
$$

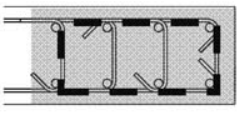

(a) N type

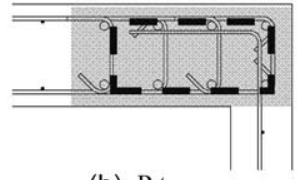

(b) P type

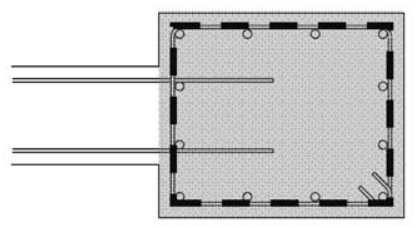

(c) C type

図 $15 A_{g}$ と $A_{c h}$ の定義

ここで, $Q_{\max }$ : 最大耐力時のせん断力である。

式(12)中の $A$ を文献 2)の算出方法による断面積（耐力壁の壁厚と 耐力壁側柱の中心間距離の積 (図 13 の斜線部分)), および拘束域断 面積 $A_{g}$ (式(10)参照） とし算出した $\tau_{l} / F_{c}$ を横軸に, 限界曲げ変形角 を縦軸にとった関係を図 14(1), (m)に示す。前者の相関係数は-0.74, 後者では-0.81 と強い負の相関があることを確認した。

\section{(10) 壁厚/中立軸長さ比}

筆者らの既往の研究 ${ }^{8)}$ において強い相関が確認された指標である 壁厚/中立軸長さ比 $\left(t / x_{n}\right)$ に関して検討を行う。 $t / x_{n}$ を横軸に, 限界 曲げ変形角を縦軸にとった関係を図 14(n)に示す。両者の相関係数は 0.54 であり, 弱い正の相関が確認された。文献 8)では表 4 の試験体 $\mathrm{N}, \mathrm{N}(\mathrm{s} 70), \mathrm{N}(\mathrm{M} / \mathrm{Qd} 3.1), \mathrm{C}$ を除く計 10 体の試験体に対し同様の分 析を行い, 相関係数 0.91 と高い相関が得られている。本稿と文献 8)では曲げ変形成分の抽出方法が異なるが, 本稿でも上記の 10 体に ついて相関係数を再評価すると 0.89 であった。本稿で新たに報告し た試験体はとくに壁板端部拘束域の構造詳細が既往の 10 体と異な っており (2.1 節参照), 曲げ圧縮破壊する耐震壁の曲げ変形性能が 少なからず拘束域の構造詳細の影響を受けることを裹付けている。

\section{(11) 拘束域軸力比}

実験では拘束域断面積を大きくすることで変形性能が向上する傾 向を確認した。そこで, 限界変形時に圧縮破壊する拘束域の性能は 軸力比 $\eta_{c}$ との相関が強いと判断し, 変形性能との関係を比較する。 $\eta_{c}$ は式(13)により評価した。

$$
\eta_{c}=\frac{N+\sum a_{t} \sigma_{y}}{A_{g} \times f^{\prime}{ }_{c}+\sum a_{c} \sigma_{y}}
$$

$\eta_{c}$ を横軸に, 限界曲げ変形角を縦軸にとった関係を図 $14(0)$ に示す。 両者の相関係数は-0.82 であり, 本稿の検討の範囲内では最も強い負 の相関があることを確認した。

以上の(1)〜(11)より, 曲げ圧縮破壞する耐震壁の曲げ変形性能と 壁板端部拘束域の構造因子の相関を分析した結果, 拘束域軸力比が 最も強い相関を示した。従って, この種の耐震壁の曲げ変形性能を 本指標により定量的に評価し得る可能性があるため, 今後は解析的 な分析を加えて, 両者の相関を定量的に評価する計画である。また, 平均せん断応力度/コンクリート圧縮強度比も高い相関を示したた め, 現行の構造規定においてもこの種の耐震壁の変形性能を一定の 精度で評価できていると判断される。実際の壁板端部拘束域には曲 
げによる軸圧縮応力度とせん断応力度が複合して作用するため, 本 質的には主応力度により評価す心゙き可能性は否定できないが, 実用 性を考慮すると軸応力度とせん断応力度に基づく評価が合理的と考 えられる。その他, 比較的高い相関を示した指標中, 拘束域長さと 壁厚/中立軸長さ比は, それぞれ上記(1)や文献 8)より, 曲げ変形性 能との物理的な関倸が明確なため拘束域軸力比に代替する評価指標 となり得る。ただし, 前者は断面の作用応力度, 後者は断面の構造 詳細を適切に考慮する必要がある。その他の構造因子についてはそ れらが単独で曲げ変形性能と定量的な相関を有するとは考えにくい が, 仕様規定には重要な役割を果たすと判断され, とくに部材種別 判定などの性能評価法の適用範囲を制限する指標となり得る。

\section{5. まとめ}

本研究では, 曲げ圧縮破壊する $\mathrm{RC}$ 耐震壁の壁板端部の拘束域の 構造詳細などを変動因子とする構造実験を行った。さらに, 先行研 究を含む実験結果を整理し, 壁板端部の拘束域の構造因子が曲げ変 形性能に与える影響について検討した。以下に, 本研究より得られ た知見をまとめる。

[構造実験による知見]

(1) すべての試験体は危険断面の圧縮側と引張側で平面が保持さ れていなかった。試験体は最終的に曲げ圧縮破壊したため, 本稿では圧縮側の曲率分布に基づいて試験体の曲げ変形成分 を抽出した。

（2) 本稿で報告した実験の範囲では, 拘束域断面積を大きくする, 壁横筋と端部拘束筋を二段ごとに束ねる（配筋間隔を大きく する), シアスパン比を大きくし（試験体に作用するせん断力 を小さくし）且つ拘束筋を閉鎖型とすることで曲げ変形性能 が向上した。とくに $90^{\circ}$ フックの拘束筋が配された耐震壁に限 れば, 拘束筋の配筋間隔と曲げ変形性能には一義的な相関を 見積もることは適切でないと判断される。

(3) 壁脚部からの拘束域高さはヒンジ長さを超えて拘束する条件 下で, 曲げ変形性能に影響しなかった。

[拘束域の構造因子と曲げ変形性能の相関]

(4) 拘束域の各種構造因子と曲げ変形性能の相関を分析した結果, 平均せん断応力度/コンクリート圧縮強度比および拘束域軸力 比と曲げ変形性能の関係に強い相関が観られた。

(5) 拘束域長さ, 主筋比, 拘束筋体積比, 壁厚/中立軸長さ比と曲 げ変形性能の関係にも比較的高い相関係数 $(0.5 \sim 0.8)$ が得ら れた。ただし, 主筋比については, これが大きいほど変形性 能が低下寸る負の相関であり, 対象とした試験体に固有の構 造詳細（大半の試験体の主筋量が同一であり，拘束域断面積 が大きいほど主筋比が小さい）が影響した可能性がある。

(6) 拘束域軸力比, 平均せん断応力度/コンクリート圧縮強度比, 拘束域長さ, 壁厚/中立軸長さ比は曲げ変形性能との物理的な 関係が明確なため, 性能評価指標となり得る。これらの構造 因子と曲げ変形性能との定量的な関係を把握することが今後 の課題である。一方, その他の構造因子は単独で曲げ変形性 能と定量的な相関を有するとは考えにくいが, 性能評価の適 用範囲を制限する指標として機能し得る。

\section{謝辞}

本研究は国土交通省の平成 24 年度建築基準整備促進事業の一環 として実施した。また，本実験を行うにあたり豊橋技術科学大学の 飯塚桃子氏, 大阪大学の尹錄現氏, 山本直樹氏にご協力いただいた。 ここに記して謝意を表す。

\section{参考文献}

1) 日本建築学会 : 鉄筋コンクリート構造計算規準・同解説, 2010.2

2) 国土交通省住宅局建築指導課ほか監修：2007 年版建築物の構造関係技 術基準解説書, 2007.8

3）日本建築学会 : 鉄筋コンクリート構造計算規準・同解説，1999.11

4) 平石久廣, 都祭弘幸, 川島俊一, 井上芳生 : 偏平な付帯柱を有する連 層耐震壁の曲げ降伏後の勒性に関する実験的研究, 日本建築学会構造 系論文報告集，No.395，pp.48-59，1989.1

5)阪本康平, 坂下雅信, 河野進, 谷昌典 : 枠柱と端部拘束筋量が而震壁 の曲げ終局変形性能に及ぼす影響，コンクリート工学年次論文集, Vol.34, No.2, pp.379-384, 2012.7

6) 日本建築学会 : 2010 年チリ・マウレ沖地震被害調查報告書 2011 年ニュ ージーランド・クライストチャーチ地震被害調査報告書, 2012.9

7) John W. Wallace, Leonardo M. Massone, Patricio Bonelli, Jeff Dragovich, Rene Lagos, Carl Luders, and Jack Moehle: Damage and Implications for Seismic Design of RC Structural Wall Buildings, 2010 Maule, Chile, Earthquake Special Issue, Earthquake Spectra, Vol. 28, No. S1, pp. S281-S299, June 2012

8) 高橋之, 吉田和也, 市之瀬敏勝, 真田靖士, 松本健規, 福山洋, 諏訪 田晴彦：圧縮側に柱型がない RC 耐震壁の曲げ変形性能, 日本建築学 会構造系論文集, Vol.76, No.660, pp.371-377, 2011.2

9) 松原聡平, 真田靖士, 高橋之, 市之瀬敏勝 : 曲げ破壊型耐力壁の変形 性能に圧縮端拘束域の構造詳細が与える影響に関する実験的研究, コ ンクリート工学年次論文集, Vol.34, No.2, pp.361-366, 2012.7

10) American Concrete Institute (ACI): Building Code Requirements for Structural Concrete and Commentary (ACI 318M-11), June 2011

11) 平石久廣 : 耐震壁のせん断変形と曲げ変形の算定方法, 日本建築学会 論文報告集，No.333，pp.56-62，1983.11

12) Masanori TANI, Hiroshi FUKUYAMA and Susumu KONO: Study on Deformation Capacity of R/C Bearing Walls with Rectangular Cross-Section Based on Experimental Database, 15th World Conference on Earthquake Engineering, Sep. 2012.

13) P. Bisch, E. Carvalho, H. Degree, P. Fajfar, M. Fardis, P. Franchin, M. Kreslin, A. Pecker, P. Pinto, A. Plumier, H. Somja, and G. Tsionis: Eurocode 8: Seismic Design of Buildings Worked examples, JRC Scientific and Technical Reports, Feb. 2011

（2013年 2 月 10 日原稿受理， 2013年 5 月24日採用決定） 